\title{
Method Development and Validation for Simultaneous Estimation of Olmesartan Medoxomil and Hydrochlorothiazide by RP-HPLC
}

\author{
SURYADEVARA VIDYADHARA*, REDDYVALAM LANKAPALLI CH SASIDHAR, \\ BALLIPALLI VENKATESWARA RAO, KODURI TEJASWI and MARUPUDI RESHMA
}

\author{
Chebrolu Hanumaiah Institute of Pharmaceutical Sciences, \\ Chandramoulipuram, Chowdavaram, Guntur - 522 019, India. \\ ${ }^{*}$ Corresponding author E-mail: svidyadhara@gmail.com
}

http://dx.doi.org/10.13005/ojc/300123

(Received: September 10, 2013; Accepted: October 15, 2013)

\begin{abstract}
A simple, fast, precise reverse phase isocratic high performance liquid chromatographic (HPLC) method has been developed for the simultaneous estimation of Olmesartan medoxomil (OM) and hydrochlorothiazide (HCTZ) in marketed formulations. Estimation of drugs in this combination was done with a C18 column [ODS UG 5 column, $250 \mathrm{~mm} \times 4.5 \mathrm{~mm}$ ] using mobile phase of composition acetonitrile and phosphate buffer $(50: 50 \mathrm{v} / \mathrm{v}, \mathrm{pH} 6.8)$. The flow rate was $1.0 \mathrm{ml} / \mathrm{min}$ and the separation was monitored at $260 \mathrm{~nm}$. The retention time of $\mathrm{HCTZ}$ and OM were $3.6 \mathrm{~min}$ and $4.3 \mathrm{~min}$ respectively. The method was found to be linear over a range of $10-70 \mu \mathrm{g} / \mathrm{ml}$ for OM and $6-42 \mu \mathrm{g} / \mathrm{ml}$ for HCTZ. The method was validated according to the guidelines of International Conference on Harmonisation $(\mathrm{ICH})$ and was successfully employed in the estimation of commercial formulations.
\end{abstract}

Key words: Olmesartan medoxomil, Hydrochlorothiazide, RP-HPLC, Method validation.

\section{INTRODUCTION}

Olmesartan medoxomil(OM) is the latest angiotensin II receptor blocker approved for use as an alternative therapeutic anti-hypertensive agent. Chemically, OM is described as (5- methyl-2- oxo-1, 3- dioxol-4-yl) methyl ester of 4-(1- hydroxy-1- methylethyl)-2-propyl-1-\{[22 -(1Htetrazol- 5-yl) [1, 12 -biphenyl]-4-yl] methyl\}-1Himidazole- 5-carboxylic acid $^{1}$. Hydrochlorothiazide is one of the oldest and widely used diuretics which is also used in the treatment of hyper-tension ${ }^{2-3}$. Chemically, it is 6chloro- 3, 4-dihydro- $2 \mathrm{H}-1$, 2, 4-benzothiadiazine7-sulphonamide 1, 1- dioxide. 
Several analytical methods have been reported for the estimation of $\mathrm{HCTZ}$ in marketed formulations and United States Pharmacopoeia (USP) describes a RP-HPLC method for its estimation ${ }^{4-12}$.OM has not been described officially in any pharmacopoeia yet. Extensive literature survey revealed that very few methods were reported for the simultaneous estimation of OM and HCTZ. So, an attempt has been made to develop an accurate, precise and economically viable RP-HPLC method for the simultaneous estimation of combination of interest in the current research.

\section{MATERIALS AND METHODS}

\section{Equipment used}

The chromatographic separation was performed on Agilent 1120 compact Liquid Chromatographic system integrated with a variable wavelength programmable UV detector and a Rheodyne injector equipped with $20 \mu$ fixed loop. A reverse phase $\mathrm{C} 18$ column [Agilent ODS UG 5 column, $250 \mathrm{~mm} \times 4.5 \mathrm{~mm}$ ] was used. Elico SL 218 double beam UV-visible spectrophotometer and Axis AGN204-PO electronic balance were used for spectrophotometric determinations and weighing purposes respectively.

\section{Reagents and chemicals}

Pharmaceutical grade pure Olmesartan medoxomil and Hydrochlorothiazide were obtained as gift samples from Apotex Research Private Limited (ARPL), Bangalore and Life line Formulations, Vijayawada respectively. Marketed formulation Olsertain- $\mathrm{H} 20$ with dose of $20 \mathrm{mg}$ of $\mathrm{OM}$ and $12.5 \mathrm{mg}$ of HCTZ were procured from local market. HPLC grade Acetonitrile and Water were procured from Merck specialities private limited, Mumbai.

\section{Chromatographic conditions}

$\mathrm{C}_{18}$ column [Agilent ODS UG 5 column, $250 \mathrm{~mm} \times 4.5 \mathrm{~mm}$ ] was used for the chromatographic separation at a detection wavelength of $260 \mathrm{~nm}$. Mobile phase of composition acetonitrile and phosphate buffer, $\mathrm{pH} 6.8$ in a ratio of 50:50 was selected for elution and same mixture was used in the preparation of standard and sample solutions. Flow rate was adjusted to $1 \mathrm{ml} / \mathrm{min}$ and the injection volume was $20 \mu \mathrm{L}$.

\section{Preparation of mobile phase}

Phosphate buffer was prepared by mixing $22.4 \mathrm{ml}$ of $0.2 \mathrm{M}$ sodium hydroxide to $50 \mathrm{ml}$ of $0.2 \mathrm{M}$ potassium dihydrogen ortho phosphate and the $\mathrm{pH}$ was adjusted to $6.8 .450 \mathrm{ml}$ of buffer was added to $450 \mathrm{ml}$ of acetonitrile, filtered through $0.45 \mu$ membrane filter and sonicated for 20 minutes.

\section{Preparation of standard solutions}

$25 \mathrm{mg}$ each of OM and HCTZ were accurately weighed and transferred into two $25 \mathrm{ml}$ volumetric flasks, dissolved using mobile phase and the volume was made up with the same solvent to obtain primary stock solutions $\mathrm{A}(\mathrm{OM})$ and $\mathrm{B}$ (HCTZ) of concentration $1000 \mu \mathrm{g} / \mathrm{ml}$ of each drug. From the primary stock solutions, $10 \mathrm{ml}$ and $6 \mathrm{ml}$ were pipetted out from $A$ and $B$ respectively, transferred to a $50 \mathrm{ml}$ volumetric flask and the volume was made up with the mobile phase to obtain final concentrations of 200 and $120 \mu \mathrm{g} / \mathrm{ml}$ of OM and HCTZ respectively (working stock solution A).

\section{Preparation of sample solution}

Twenty tablets of Olsertain-H 20 were weighed and crushed. Content equivalent to 50mg $\mathrm{OM}$ and $30 \mathrm{mg}$ HCTZ was weighed accurately and transferred to a $50 \mathrm{ml}$ volumetric flask. The content was dissolved with $20 \mathrm{ml}$ of solvent and then sonicated for $15 \mathrm{~min}$. The volume was made up with the mobile phase and filtered with $0.45 \mu$ membrane filter. $1 \mathrm{ml}$ from the primary stock solution was pipetted out and transferred to a $10 \mathrm{ml}$ volumetric flask and the volume was made up with the solvent to obtain a concentration of 100 and $60 \mu \mathrm{g} / \mathrm{ml}$ of OM and HCTZ respectively (working stock solution $\mathrm{B}$ ).

\section{Optimization of HPLC method}

The HPLC method was optimized with an aim to develop a simultaneous estimation procedure for the assay of OM and HCTZ. For the method optimization, different mobile phases were tried but acceptable retention times, theoretical plates and good resolution were observed with acetonitrile and $\mathrm{pH} 6.8$ phosphate buffer $\left(50: 50\right.$, v/v) using $\mathrm{C}_{18}$ column (Agilent ODS UG column, 250mm x 4.5mm)

\section{Validation of the RP-HPLC method}

Validation of the optimized method was performed according to the ICH Q2 (B) guidelines. 


\section{System suitability}

System suitability was carried out with five injections of solution of $100 \%$ concentration having $70 \mu \mathrm{g} / \mathrm{ml}$ of $\mathrm{OM}$ and $42 \mu \mathrm{g} / \mathrm{ml}$ of $\mathrm{HCTZ}$ in to the chromatographic system. Number of theoretical plates $(\mathrm{N})$ obtained and calculated tailing factor $(\mathrm{T})$ were reported in table 1.

\section{Linearity}

For the determination of linearity, appropriate aliquots were pipetted out from working stock solution $A$ to a series of $10 \mathrm{ml}$ volumetric flasks and the volume was made up with the solvent to obtain concentrations ranging from $10-70 \mu \mathrm{g} / \mathrm{ml}$ of $\mathrm{OM}$ and 6-42 $\mu \mathrm{g} / \mathrm{ml}$ of HCTZ. Each solution was injected in triplicate. Calibration curves were plotted with observed peak areas against concentration followed by the determination of regression equations and calculation of the correlation coefficients. The calibration curves for OM and HCTZ were shown in Figure 3 and their corresponding linearity parameters were given in table 2 .

\section{Accuracy}

To ensure the reliability and accuracy of the method recovery studies were carried out by standard addition method. A known quantity of pure drug was added to pre-analysed sample and contents were reanalysed by the proposed method and the percent recovery was reported. The results were given in Table 4.

\section{Precision}

The repeatability of the method was verified by calculating the \%RSD of six replicate injections of $100 \%$ concentration $(70 \mu \mathrm{g} / \mathrm{ml}$ of $\mathrm{OM}$ and $42 \mu \mathrm{g} / \mathrm{ml}$ of $\mathrm{HCTZ}$ ) on the same day and for intermediate precision $\%$ RSD was calculated from repeated studies on different days. The results were given in table 3 .

\section{Specificity}

Specificity of a method was determined by testing standard substances against potential interferences. The method was found to be specific when the test solution was injected and no interferences were found because of the presence of excipients.

\section{Limit of detection (LOD) and limit of quantitation (LOQ)}

The LOD and LOQ were calculated from the slope(s) of the calibration plot and the standard deviation (SD) of the peak areas using the formulae $\mathrm{LOD}=3.3 \mathrm{\sigma} / \mathrm{S}$ and $\mathrm{LOQ}=10 \mathrm{\sigma} / \mathrm{S}$. the values were given in table 2 .

\section{Robustness}

Robustness of the method was verified by altering the chromatographic conditions like mobile phase composition, flow rate, detection wavelength, etc. and the \% RSD should be reported.

Small changes in the operational conditions were allowed and the extent to which the method was robust was determined. A deviation of $\pm 2 \mathrm{~nm}$ in the detection wavelength and $\pm 0.1 \mathrm{~mL} / \mathrm{min}$ in the flow rate, were tried individually. A solution of $100 \%$ test concentration with the specified changes in the operational conditions were injected to the instrument in triplicate. \%RSD was reported in table 5.

\section{Assay of marketed formulation}

$20 \mu$ l of sample solution of concentration $70 \mu \mathrm{g} / \mathrm{ml}$ of $\mathrm{OM}$ and $42 \mu \mathrm{g} / \mathrm{ml}$ of HCTZ was injected into chromatographic system and the peak responses were measured. The solution was injected three times into the column. The amount present in each tablet was calculated by comparing the areas of standards with the test samples.

\section{RESULTS AND DISCUSSION}

After a number of trials with mobile phases of different composition, acetonitrile and phosphate buffer, pH 6.8 50:50 v/v was selected as mobile phase because of better resolution and symmetrical peaks. OM and HCTZ were found to show appreciable absorbance at $260 \mathrm{~nm}$ when determined spectrophotometrically and hence it was selected as the detection wavelength. An optimized chromatogram showing the separation of HCTZ and $\mathrm{OM}$ at different $\mathrm{R}_{\mathrm{T}} \mathrm{s}$ was shown in figure 2 .

System suitability was carried out by injecting 5 replicate injections of $100 \%$ test concentration, number of theoretical plates, HETP and resolution were satisfactory. The chromatogram confirms the presence of HCTZ and OM at $3.6 \mathrm{~min}$ and $4.3 \mathrm{~min}$ respectively without any interferences. The parameters were given in table 1 . 
Table 1: System suitability parameters

\begin{tabular}{lcc}
\hline Parameters & Hydrochlorothiazide & Olmesartan medoxomil \\
\hline Retention time $(\min )$ & 3.6 & 4.3 \\
Theoretical plates $(\mathrm{N})$ & 11421 & 9897 \\
Tailing factor $(\mathrm{T})$ & 1.2 & 1.4 \\
Resolution $\left(\mathrm{R}_{\mathrm{s}}\right)$ & & 1.9 \\
\hline
\end{tabular}

Table 2: Results for Linearity $(n=3)$

\begin{tabular}{lcc}
\hline Parameters & Hydrochlorothiazide & Olmesartan medoxomil \\
\hline Slope & 963140 & 727006 \\
Intercept & 586967 & 17530 \\
$\mathrm{r}^{2}$ & 0.9996 & 0.9996 \\
Regression equation & $\mathrm{y}=963140 \mathrm{x}+586967$ & $\mathrm{y}=727006 \mathrm{x}+17530$ \\
Linearity range & $6-42 \mu \mathrm{g} / \mathrm{ml}$ & $10-70 \mu \mathrm{g} / \mathrm{ml}$ \\
LOD & $0.10 \mu \mathrm{g} / \mathrm{ml}$ & $0.25 \mu \mathrm{g} / \mathrm{ml}$ \\
LOQ & $0.32 \mu \mathrm{g} / \mathrm{ml}$ & $0.78 \mu \mathrm{g} / \mathrm{ml}$ \\
\hline
\end{tabular}

${ }^{*} \mathrm{n}=$ No. of determinants

Table 3: Results for Precision $(n=6)$

\begin{tabular}{lcc}
\hline Drug & $\begin{array}{c}\text { Intraday } \\
\text { Precision (\% RSD) }\end{array}$ & $\begin{array}{c}\text { Interday } \\
\text { Precision (\% RSD) }\end{array}$ \\
\hline Hydrochlorothiazide & 0.69 & 1.13 \\
Olmesartan medoxomil & 0.57 & 0.72 \\
\hline${ }^{*} \mathrm{n}=$ No. of determinants & &
\end{tabular}

Table 4: Results for Accuracy $(n=3)$

\begin{tabular}{|c|c|c|c|c|c|c|c|c|}
\hline \multirow{2}{*}{$\begin{array}{l}\text { Recovery } \\
\text { level }\end{array}$} & \multicolumn{4}{|c|}{ Olmesartan medoxomil } & \multicolumn{4}{|c|}{ Hydrochlorothiazide } \\
\hline & \multicolumn{2}{|c|}{$\begin{array}{l}\text { Amount } \\
\text { Added } \\
(\mu \mathrm{g} / \mathrm{mL})\end{array}$} & Amount & $\begin{array}{c}\% \\
\text { Found } \\
\text { ( } \mu \mathrm{g} / \mathrm{mL})\end{array}$ & $\begin{array}{c}\begin{array}{c}\text { Amount } \\
\text { Recovery }\end{array} \\
\text { Std. }\end{array}$ & $\begin{array}{l}\text { A } \\
\text { Addec } \\
\text { test }\end{array}$ & $\begin{array}{l}\text { Amount } \\
\text { d Found } \\
(\mu \mathrm{g} / \mathrm{mL})\end{array}$ & $\begin{array}{c}\% \\
\text { d Recovery } \\
(\mu \mathrm{g} / \mathrm{mL})\end{array}$ \\
\hline $80 \%$ & 40 & 10 & 49.51 & 99.02 & 24 & 6 & 30.28 & 100.94 \\
\hline $100 \%$ & 50 & 10 & 60.93 & 101.55 & 30 & 6 & 36.21 & 100.59 \\
\hline $120 \%$ & 60 & 10 & 69.61 & 99.44 & 36 & 6 & 41.32 & 98.39 \\
\hline Mean Recovery & \multicolumn{4}{|c|}{$99.02-101.55 \% \mathrm{w} / \mathrm{w}$} & \multicolumn{4}{|c|}{$98.39-100.94 \% w / w$} \\
\hline
\end{tabular}

${ }^{*} \mathrm{n}=$ No. of determinants 
Table 5: Results for Robustness

\begin{tabular}{lcc}
\hline \multirow{2}{*}{ Parameters $(\mathbf{n}=\mathbf{3})$} & \multicolumn{2}{c}{ \% RSD } \\
\cline { 2 - 3 } & Hydrochlorothiazide & Olmesartan medoxomil \\
\hline At $\lambda \max 258 \mathrm{~nm}$ & 0.42 & 0.43 \\
At $\lambda$ max $262 \mathrm{~nm}$ & 0.71 & 0.59 \\
With flow rate $0.9 \mathrm{ml}$ & 0.66 & 0.48 \\
With flow rate $1.1 \mathrm{ml}$ & 0.72 & 0.78 \\
\hline
\end{tabular}

${ }^{*} \mathrm{n}=$ No. of determinants

Table 6: Results for Assay $(n=3)$ of marketed formulation

\begin{tabular}{lccc}
\hline Drug & Label claim (mg/tab) & Amount recovered & \% Amount found in drug \\
\hline OM & $20 \mathrm{mg}$ & $20.06 \mathrm{mg}$ & $100.34 \% \mathrm{w} / \mathrm{w}$ \\
$\mathrm{HCTZ}$ & $12.5 \mathrm{mg}$ & $12.4 \mathrm{mg}$ & $99.2 \% \mathrm{w} / \mathrm{w}$ \\
\hline
\end{tabular}

${ }^{*} n=$ No. of determinants

Concentration range of $10-70 \mu \mathrm{g} / \mathrm{ml}$ for OM and $6-42 \mu \mathrm{g} / \mathrm{ml}$ for HCTZ were found to be linear with correlation coefficients 0.9996 and 0.9996 for OM and HCTZ respectively. The results were given in table 2.

The proposed method was found to be precise and reproducible with \%RSD of 1.13 and 0.72 for HCTZ and OM respectively. \%RSD was reported in table 3 .<smiles>CCCc1nc(C(C)(C)O)c(C(=O)Cc2oc(=O)oc2C)n1Cc1ccc(-c2ccccc2-c2nnn[nH]2)cc1</smiles>

a) Olmesartan medoxomil
Accuracy of the method was verified by performing recovery studies by standard addition method. The percent recovery of the standard added to the pre-analysed sample was calculated and it was found to be 98.39 to $100.94 \% \mathrm{w} / \mathrm{w}$ and 99.02 $101.55 \%$ ww/w for HCTZ and OM respectively which indicates that the method was accurate. Values obtained were given in table 4 .<smiles>NS(=O)(=O)c1cc2c(cc1Cl)NCNS2(=O)=O</smiles>

b) Hydrochlorothiazide

Fig. 1: Chemical Structures of a) OM and b)HCTZ 
The limits of detection for HCTZ and OM were found to be $0.106 \mu \mathrm{g} / \mathrm{ml}$ and $0.259 \mu \mathrm{g} / \mathrm{ml}$ respectively and the limits of quantitation were 0.323 $\mu \mathrm{g} / \mathrm{ml}$ and $0.786 \mu \mathrm{g} / \mathrm{ml}$ respectively.
The method was found to be specific for the combination of interest after verifying the chromatograms showing no interference of the excipients present. Hence, the method was well

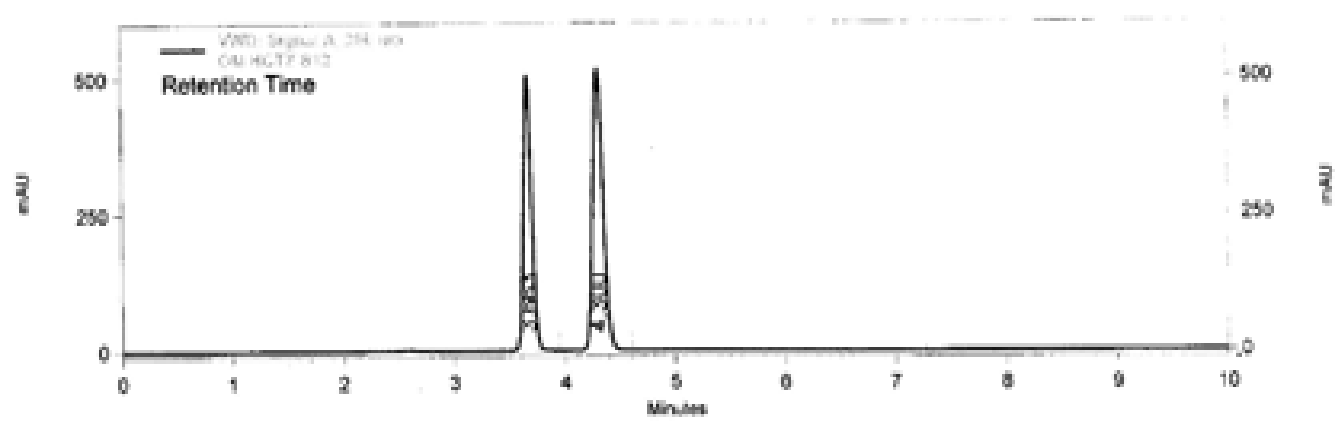

Fig. 2: Optimized chromatogram of HCTZ and OM by RP-HPLC

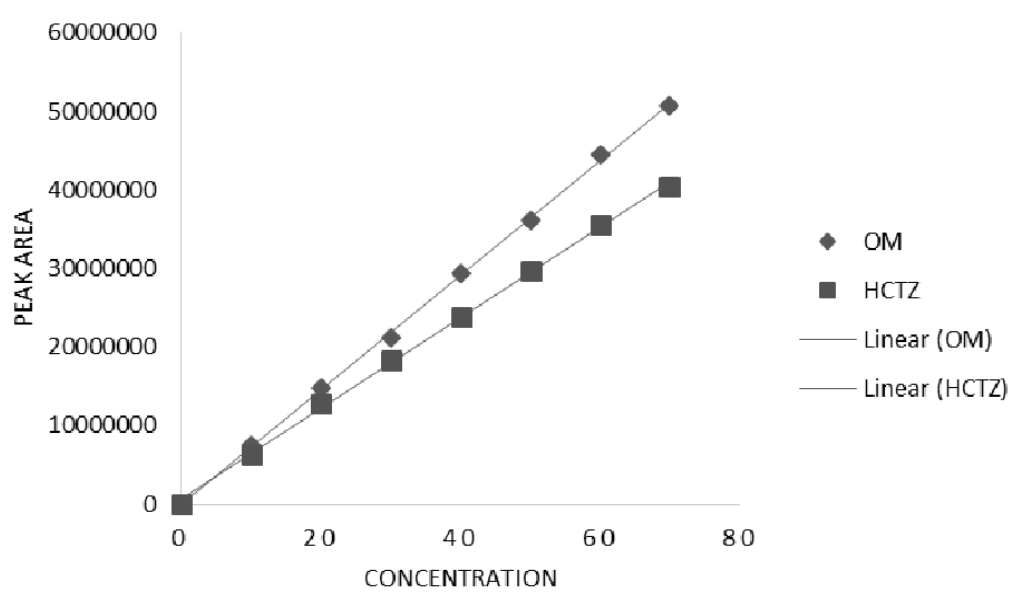

Fig. 3: Calibration Plot of Olmesartan medoxomil and Hydrochlorothiazide

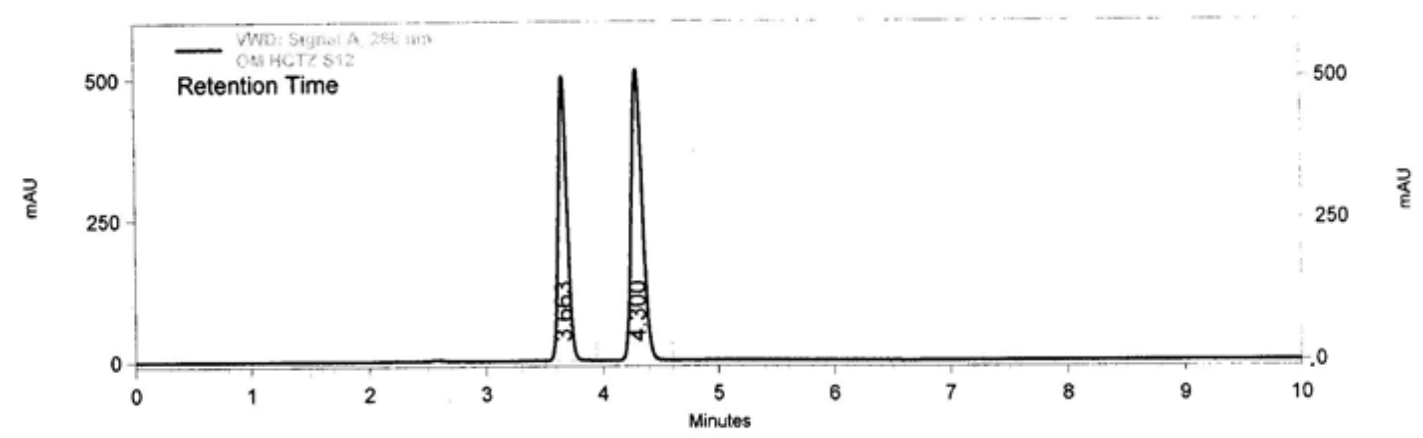

Fig. 4: A typical chromatogram for assay of marketed formulation containing $42 \mu \mathrm{g} / \mathrm{ml}$ of HCTZ and $70 \mu \mathrm{g} / \mathrm{ml}$ of OM 
suitable for the estimation of the commercial formulations of the selected combination. Values obtained were given in table 5 .

The method was found to be robust after changing the conditions like detection wavelength ( \pm $2 \mathrm{~nm})$ and flow rate $( \pm 0.1 \mathrm{ml})$. \%RSD was calculated for each variation and reported. Values obtained were given in table 6 .

\section{CONCLUSION}

The HPLC method developed and validated allows a simple and fast quantitative determination of Olmesartan medoxomil and Hydrochlorothiazide from its formulation. All the validation parameters were found to be within the limits according to the $\mathrm{ICH}$ guidelines. The proposed method was found to be specific for the drugs of interest irrespective of the excipients present and the method was found to be simple, accurate, precise, rugged, robust and can be involved in the routein analysis of the marketed formulations.

\section{ACKNOWLEDGEMENTS}

The authors are thankful to the Apotex Research Private Limited (ARPL), for providing gift sample of Olmesartan medoxomil, Life line Formulations, for providing gift sample of Hydrochlorothiazide respectively, and also to the management of Chebrolu Hanumaiah Institute of Pharmaceutical Sciences, Chowdavaram, Guntur for providing facilities and great support to carry out the research work.

\section{REFERENCES}

1. Connick R. E. and Hugus Z. Z., J. Am. Chem. Soc., 75: 6012 (1988)

2. Hans R.B. Vasc Health Risk Manag., 2: 327-340 (2006).

3. G.S. Devika, M. Sudhakar and J.Venkateshwar Rao, Orient J. Chem., 28(2): 887-893 (2012).

4. Beermann B, Groschinsky-Grind $M$ and Rosen A. Clin Pharmacol Ther., 19: 531-7 (1976)

5. Raja B and Lakshmana Rao A. Int $J$ Res Pharm Chem., 03: 714-717 (2011)

6. Raveendra G.B, Ramprasad LA, Srinivasu P, Jayachandra PR and Mustafa M. Eurasian $J$. Anal. Chem., 5: 145-151 (2009)

7. Parthiban C, Bhagavan Raju M and Sudhakar M. Int J Pharm Indus Res., 1: 325-329
(2011).

8. F. Shokraneh, A. Dabirsiaghi and N. Adib, Orient J. Chem., 28(1): 237-241 (2012).

9. Della Grace T.P, Molly M, Ganesan V, Anila J and Revikumar K.G. Int Jour Pharm Sci Rev Res., 4: 36-39 (2010).

10. Vachhani K.H and Patel Satish A. Journal of Applied Pharmaceutical Science., 1: 112-115 (2011).

11. Chouhan K.S, Bhure M.V, Hemke A.T, Gupta K.R, Wadodkar S.G. Res. J. Pharm. Biol. Chem. Sci., 1: 78-84 (2010).

12. Hasan M, Al Masud A, Ahmed J. International journal of Pharmaceutical sciences and research., 1: 80-84. (2010).

13. Maher K, Numan M, Murad A, Raqi S, Nidal J. Int J Pharm Pharm Sci., 4: 683-687 (2012). 